\title{
Review Article \\ Human Paraoxonase 1 as a Pharmacologic Agent: Limitations and Perspectives
}

\author{
Priyanka Bajaj, Rajan K. Tripathy, Geetika Aggarwal, and Abhay H. Pande \\ Department of Biotechnology, National Institute of Pharmaceutical Education and Research (NIPER), Sector 67, \\ Sahibzada Ajit Singh Nagar, Punjab 160062, India \\ Correspondence should be addressed to Abhay H. Pande; apande@niper.ac.in
}

Received 11 May 2014; Revised 13 August 2014; Accepted 27 August 2014; Published 20 October 2014

Academic Editor: Srinivasa Reddy

Copyright (c) 2014 Priyanka Bajaj et al. This is an open access article distributed under the Creative Commons Attribution License, which permits unrestricted use, distribution, and reproduction in any medium, provided the original work is properly cited.

Human PON1 (h-PON1) is a multifaceted enzyme and can hydrolyze (and inactivate) a wide range of substrates. The enzyme shows anti-inflammatory, antioxidative, antiatherogenic, ant-diabetic, antimicrobial, and organophosphate (OP)-detoxifying properties. However, there are certain limitations regarding large-scale production and use of h-PON1 as a therapeutic candidate. These include difficulties in producing recombinant h-PON1 (rh-PON1) using microbial expression system, low hydrolytic activity of wild-type h-PON1 towards certain substrates, and low storage stability of the purified enzyme. This review summarizes the work done in our laboratory to address these limitations. Our results show that (a) optimized polynucleotide sequence encoding rh-PON1 can express the protein in an active form in E. coli and can be used to generate variant of the enzyme having enhanced hydrolytic activity, (b) in vitro refolding of rh-PON1 enzyme can dramatically increase the yield of an active enzyme, (c) common excipients can be used to stabilize purified rh-PON1 enzyme when stored under different storage conditions, and (d) variants of rh-PON1 enzyme impart significant protection against OP-poisoning in human blood (ex vivo) and mouse (in vivo) model of OP-poisoning. The rh-PON1 variants and their process of production discussed here will help to develop h-PON1 as a therapeutic candidate.

\section{Introduction}

Human paraoxonase 1 (h-PON1) (EC 3.1.8.1) is a $\sim 43 \mathrm{kDa}$ polypeptide of 355 amino acids $[1,2]$. It is primarily synthesized in the liver and is secreted into the bloodstream where it is associated with a category of high density lipoprotein particles [3-6]. The h-PON1 is a multitasking enzyme and can hydrolyze different types of substrates. Various hydrolytic activities of h-PON1 can be broadly grouped into three categories: arylesterase, phosphotriesterase, and lactonase [7]. The enzyme exhibits anti-inflammatory, antioxidative, antiatherogenic, antidiabetic, antimicrobial, and OPneutralizing properties $[1,8-12]$. Recent reports suggest that h-PON1 also plays an important role in the metabolism of certain drugs [13-15].

\section{Protective Role of PON1 and PON1 as a Potential Therapeutic Candidate}

The level and the activity of serum PON1 in individuals suffering from cardiovascular diseases, liver diseases, diabetes, renal diseases, cancer, and obesity are considerably lower than in the normal subjects $[5,16-21]$. The level and the activity of circulating PON1 are also considered as novel biomarkers for the evaluation of these diseases in humans [22-26]. Animals deficient in PON1 have been found to be more susceptible to these disease conditions and the overexpression of hPON1 or administration of purified PON1 in these animals has been shown to prevent/retard the development of these disease conditions [10, 12, 27-30]. The beneficial role of $h$ PON1 in OP-poisoning is also well demonstrated. Animals deficient in PON1 (knockout animals) have been found to be more susceptible to OP-poisoning compared to their wildtype counterpart and administration of purified PON1 has been shown to provide protection against OP-poisoning in various animal models [12, 31-39]. In some cases, PON1 has been shown to provide better protection than the existing antidotes of OP-poisoning [40]. Antimicrobial role of PON1 is also well documented in the literature $[8,41,42]$. Thus, hPON1 has emerged as a strong candidate for the development of therapeutic intervention against a variety of conditions in humans $[8,12,43-55]$. 


\section{Problems Associated with the Development of h-PON1 as a Therapeutic Candidate}

Native h-PON1 does not have sufficiently high hydrolytic activity against all its substrates; therefore, there is a need to develop improved variant(s) of h-PON1 having enhanced hydrolytic activity against desired substrate(s) $[45,56,57]$. This can be done by protein engineering in which changing the amino acid residue at a particular position in h-PON1 can develop a variant of the enzyme having enhanced hydrolytic activity. To do this, a simple system for the expression and the production of rh-PON1 is urgently needed. E. coli expression system is the most preferred system for the manufacture of recombinant proteins [58-60]. This system also permits easy genetic manipulation to generate desired variant(s) of the target recombinant protein, characterization of which can also help in elucidating the mechanism of action of the target protein.

The production of rh-PON1 in high yield and in functionally active form using an E. coli expression system has been difficult until now $[27,36,61,62]$. Numerous complex approaches were used earlier to generate active rh-PON1 with high purity and high yield using this expression system (e.g., generation of gene family reshuffled chimeric-PON1 (Chi-PON1) [27], addition of $>5$ extra amino acids to the recombinant enzyme [63], and use of specialized E. coli cells which contain additional "helper" plasmid(s) $[36,63])$. These approaches resulted in either considerable alteration in the original amino acid sequence of the h-PON1 or significantly low yield of the recombinant protein.

\section{Polymorphism in PON1 and Generation of Improved Variants}

The crystal structure of h-PON1 has not been solved yet and the molecular details of how the enzyme hydrolyzes different types of substrates are also not clear. Literature suggests that amino acid residues at positions 115 and 192 in h-PON1 play an important role in modulating the hydrolytic activities of the enzyme $[56,64,65]$. In native h-PON1, histidine $(\mathrm{H})$ residue occupies 115 and 134 positions while glutamine (Q) or arginine (R) is present at position 192. It is proposed that $\mathrm{H} 115$ forms a catalytic dyad with $\mathrm{H} 134$ and participates in the hydrolytic activity of PON1. Presence of $\mathrm{Q} / \mathrm{R}$ at position 192 of PON1 dramatically affects the hydrolytic properties of the enzyme towards particular substrate(s). Alloform of h-PON1 containing $\mathrm{R}$ at position 192 efficiently degrades paraoxon while alloform carrying $\mathrm{Q}$ at the same position possesses better hydrolytic activity towards soman and sarin $[9,66-68]$. Interestingly, PON1 from rabbit plasma contains lysine $(\mathrm{K})$ residue at position 192 and exhibits very high hydrolytic activity towards paraoxon and lactones [69]. Recently, it was observed that substitution of $\mathrm{H} 115$ with tryptophan (W) residue increases the hydrolytic activity of the enzyme towards OP-compounds and decreases the lactone- and arylesterhydrolyzing activities of the enzyme $[27,56,65,70]$. Based on this information and in order to understand how the enzyme hydrolyzes different types of substrates, we have generated and characterized the following variants of rh-PON1 ${ }_{(\mathrm{wt})}$ : rh$\mathrm{PON1}_{(\mathrm{H} 115 \mathrm{~W})}$, rh-PON1 $1_{(\mathrm{H} 115 \mathrm{~W} ; \mathrm{R} 192 \mathrm{~K})}, \mathrm{rh}_{-\mathrm{PON1}} 1_{(\mathrm{H} 115 \mathrm{~W} ; \mathrm{R} 192 \mathrm{Q})}$, rh-PON1 ${ }_{(\mathrm{H} 115 \mathrm{~W} ; \mathrm{H} 134 \mathrm{R})}$, rh-PON1 $1_{(\mathrm{H} 115 \mathrm{~W} ; \mathrm{H} 134 \mathrm{R} ; \mathrm{R} 192 \mathrm{~K})}$, and rh$\mathrm{PON1}_{\text {(L69G;S111T;H115W;H134R;R192K;F222S;T332S) }}[71,72]$.

\section{Expression of Active rh-PON1 Enzymes in E. coli}

In order to express rh-PON1 enzymes in the active form in E. coli, codon optimized genes encoding rh-PON1 enzymes were generated and expressed in E. coli. rh-PON1 enzymes were expressed in soluble and active form and as (His) ${ }_{6}$ tagged proteins. These recombinant enzymes are referred as "soluble" to differentiate them from the refolded enzymes described later in this report. The recombinant proteins were purified to homogeneity using a two-step chromatographic procedure $[71,72]$. Using this procedure, we were able to get a yield of $0.2-0.25 \mathrm{mg}$ of pure and active $\mathrm{rh}-\mathrm{PON1} / \mathrm{g}$ wet cell mass of $E$. coli. Characterization of rh-PON1 enzymes revealed that $\mathrm{rh}-\mathrm{PON1}_{(\mathrm{wt})}$ is similar to native h-PON1 in terms of its hydrolytic activities as well as its amino acid sequence $[71,72]$.

Although we managed to express rh-PON1 enzymes in active form in E. coli, the final yield of the purified protein was very low despite growing the cells expressing rh-PON1 enzyme at a low temperature and inducing the expression of recombinant protein by using low concentration of inducer (i.e., IPTG), the two most important parameters that promote the expression of recombinant proteins in active form in $E$. coli $[73,74]$.

\section{Production of rh-PON1 Enzymes by Refolding of Inclusion Bodies (IBs)}

Being a eukaryotic protein, overexpression of rh-PON1 in E. coli leads to aggregation of the overexpressed protein in inactive form as IBs. Thus, it is difficult to express active rh-PON1 enzyme in high amount in E. coli $[43,61,62]$. Also, for the purification of recombinant proteins expressed in low amount, the presence of "tag" in the recombinant protein is essential [74]. Although, this "tag" helps in easy purification of the recombinant protein (by using affinity chromatography), it may lead to complications when such tag-containing proteins are used as drugs in physiological conditions [74].

In vitro refolding of recombinant proteins present in inactive form in IBs to their active form has emerged as an attractive alternative over production of soluble and active recombinant proteins [75-77]. However, in vitro refolding of recombinant proteins is considered as a major bottleneck in protein production scheme [75-77]. We have developed a method for production of active rh-PON1 enzymes in high yield by in vitro refolding of IBs [78]. The (His) ${ }_{6}$-tag present in the rh-PON1 enzymes was removed and the rhPON1 enzymes containing no (His) 6 -tag were overexpressed in $E$. coli as IBs. The IBs were purified and the recombinant proteins were refolded (to their active form) by diluting the 
denatured protein into refolding buffer. The active enzymes were isolated from the refolding mixture by ion-exchange chromatography. Dilution along with additive assisted refolding method is a widely preferred approach for industrial scale production of recombinant proteins over other methods of in vitro refolding [79]. Enzymatic characterization of refolded rh-PON1 enzymes indicated that the catalytic properties of the refolded enzymes were similar to their soluble counterparts. The refolded rh-PON1 enzymes have $100 \%$ amino acid sequence identity to native h-PON1, with minimal changes necessary for enhancing its hydrolytic activity, and are devoid of any "tag" or extra amino acids. By using the procedure of in vitro refolding and isolation of active protein, we were able to get a yield which is significantly higher than the yield of rh-PON1 reported in the literature [78].

\section{Storage Stability of Purified rh-PON1 Enzymes}

Purified h-PON1 (recombinant or isolated from human plasma) is relatively unstable and rapidly loses its enzymatic activity when stored in aqueous buffer at $25^{\circ} \mathrm{C}$ or $4^{\circ} \mathrm{C}$ [8085]. h-PON1 is an important protein and for successful commercial applications and use, long-term storage stability of purified rh-PON1 enzyme is important. A few attempts were made earlier by researchers to increase the stability of PON1 protein $[40,85]$. But in these studies, complex physiological counterparts of h-PON1 (like reconstituted HDL [40] or human phosphate binding protein (HPBP) [85]) had been used to stabilize r-PON1. However, till now no detailed studies have been carried out to find simpler pharmaceutical excipients that can ensure continued storage of purified hPON1 under different storage conditions without loss of its enzymatic activity.

To increase their shelf life, biotechnologically important proteins are usually stored as liquid or lyophilized formulations. We have screened various excipients for their ability to stabilize rh-PON1 when stored in either aqueous solution or lyophilized form at $25^{\circ} \mathrm{C}$ [86]. Our results show that glycine and serine are most effective in stabilizing the enzyme when stored in aqueous buffer at $25^{\circ} \mathrm{C}$, and trehalose, maltose, and BSA exerted maximum stabilization effect when the enzyme was stored in the lyophilized form at $25^{\circ} \mathrm{C}$ [86]. The results suggest that simpler pharmaceutical excipients can be used to stabilize purified rh-PON1 enzymes when stored for a long period of time under different storage conditions and these results can be used to develop formulation(s) of rh-PON1 enzymes for commercial use.

\section{Prophylactic Activity of Refolded rh-PON1 Enzyme against OP-Poisoning}

OP-compounds are toxic chemicals that exert their deleterious effect by inhibiting neurotransmitter-metabolizing enzymes [87, 88]. Current treatments available for OPpoisoning are considered as unsatisfactory and inadequate, and there is an urgent need for the development of more effective treatment for OP-poisoning [44-49]. h-PON1 is a strong candidate for the development of prophylactic and therapeutic agent against OP-poisoning in humans [44-49].

Prophylactic activity of refolded rh-PON1 enzyme was studied using mouse model of OP-poisoning [11, 40]. Our results show that the refolded rh-PON1 enzyme was not toxic and was safely tolerated by the animals and pretreatment with refolded rh-PON1 enzyme imparted protection against OPpoisoning in mice [78].

\section{Conclusion}

$\mathrm{H}-\mathrm{PON} 1$ is a versatile protein and possesses multiple beneficial properties. It is a potential candidate for the development of therapeutic intervention against OP-poisoning and other disease conditions in humans. Availability of a procedure to produce rh-PON1 enzymes in pure form and high yield by using microbial expression system will help tremendously in generating variants of $h-P O N 1$, characterization of which will increase our knowledge about the catalytic mechanism of the enzyme. This will also help in producing desired variant(s) of h-PON1 enzyme in large quantity so that the therapeutic potential of such variant(s) can be tested in various animal models. This will certainly help in developing h-PON1 as a pharmacologic agent in future.

\section{Conflict of Interests}

A patent application has been filed related to the products and technology described in this paper by the National Institute of Pharmaceutical Education and Research (NIPER), Sahibzada Ajit Singh Nagar. AHP, PB, RKT and GA are inventors in that patent application and hold an indirect interest in this intellectual property.

\section{Acknowledgments}

This work was supported by the research grants to AHP from NIPER, SAS Nagar. Priyanka Bajaj (CSIR-SPM-SRF) and Geetika Aggarwal (CSIR-SRF) are thankful to CSIR, New Delhi, for financial support in the form of CSIR Fellowship. The authors are grateful to Professor Dan S. Tawfik (Weizmann Institute of Science, Rehovot, Israel) for kindly providing them with the plasmid containing Chi-PON1. The authors thank Dr. Ipsita Roy, Department of Biotechnology, NIPER, SAS Nagar, for her valuable assistance in correcting the language of this paper.

\section{References}

[1] Z. Ahmed, A. Ravandi, G. F. Maguire et al., "Multiple substrates for paraoxonase-1 during oxidation of phosphatidylcholine by peroxynitrite," Biochemical and Biophysical Research Communications, vol. 290, no. 1, pp. 391-396, 2002.

[2] B. N. La Du, S. Adkins, C.-L. Kuo, and D. Lipsig, "Studies on human serum paraoxonase/arylesterase," Chemico-Biological Interactions, vol. 87, no. 1-3, pp. 25-34, 1993.

[3] M. I. Mackness, B. Mackness, P. N. Durrington, P. W. Connelly, and R. A. Hegele, "Paraoxonase: biochemistry, genetics 
and relationship to plasma lipoproteins," Current Opinion in Lipidology, vol. 7, no. 2, pp. 69-76, 1996.

[4] M. Rosenblat, L. Gaidukov, O. Khersonsky et al., "The catalytic histidine dyad of high density lipoprotein-associated serum paraoxonase-1 (PON1) is essential for PON1-mediated inhibition of low density lipoprotein oxidation and stimulation of macrophage cholesterol efflux," The Journal of Biological Chemistry, vol. 281, no. 11, pp. 7657-7665, 2006.

[5] M. Boshtam, A. E. Razavi, M. Pourfarzam et al., "Serum paraoxonase 1 activity is associated with fatty acid composition of high density lipoprotein," Disease Markers, vol. 35, no. 4, pp. 273-280, 2013.

[6] A. Gugliucci, M. Numaguchi, R. Caccavello, and S. Kimura, "Paraoxonase 1 lactonase activity and distribution in the HDL subclasses in the cord blood," Redox Report, vol. 19, no. 3, pp. 124-132, 2014.

[7] S. Billecke, D. Draganov, R. Counsell et al., "Human serum paraoxonase (PON1) isozymes $\mathrm{Q}$ and $\mathrm{R}$ hydrolyze lactones and cyclic carbonate esters," Drug Metabolism and Disposition, vol. 28, no. 11, pp. 1335-1342, 2000.

[8] J. Camps, I. Pujol, F. Ballester, J. Joven, and J. M. Simó, "Paraoxonases as potential antibiofilm agents: their relationship with quorum-sensing signals in gram-negative bacteria," Antimicrobial Agents and Chemotherapy, vol. 55, no. 4, pp. 13251331, 2011.

[9] L. G. Costa, R. J. Richter, W.-F. Li, T. Cole, M. Guizzetti, and C. E. Furlong, "Paraoxonase (PON1) as a biomarker of susceptibility for organophosphate toxicity," Biomarkers, vol. 8, no. 1, pp. 1-12, 2003.

[10] M. Koren-Gluzer, M. Aviram, E. Meilin, and T. Hayek, "The antioxidant HDL-associated paraoxonase-1 (PON1) attenuates diabetes development and stimulates $\beta$-cell insulin release," Atherosclerosis, vol. 219, no. 2, pp. 510-518, 2011.

[11] W. F. Li, C. E. Furlong, and L. G. Costa, "Paraoxonase protects against chlorpyrifos toxicity in mice," Toxicology Letters, vol. 76, no. 3, pp. 219-226, 1995.

[12] D. M. Shih, L. Gu, Y.-R. Xia et al., "Mice lacking serum paraoxonase are susceptible to organophosphate toxicity and atherosclerosis," Nature, vol. 394, no. 6690, pp. 284-287, 1998.

[13] G. Campo, M. Miccoli, M. Tebaldi et al., "Genetic determinants of on-clopidogrel high platelet reactivity," Platelets, vol. 22, no. 6, pp. 399-407, 2011.

[14] T. Yin and T. Miyata, "Pharmacogenomics of clopidogrel: evidence and perspectives," Thrombosis Research, vol. 128, no. 4, pp. 307-316, 2011.

[15] L. Zhang, Y. Chen, Y. Jin et al., "Genetic determinants of high on-treatment platelet reactivity in clopidogrel treated Chinese patients," Thrombosis Research, vol. 132, no. 1, pp. 81-87, 2013.

[16] O. Fridman, A. G. Fuchs, R. Porcile, A. V. Morales, and L. O. Gariglio, "Paraoxonase: its multiple functions and pharmacological regulation," Archivos de Cardiologia de Mexico, vol. 81, no. 3, pp. 251-260, 2011.

[17] J. Valabhji, A. J. McColl, M. Schachter, S. Dhanjil, W. Richmond, and R. S. Elkeles, "High-density lipoprotein composition and paraoxonase activity in type 1 diabetes," Clinical Science, vol. 101, no. 6, pp. 659-670, 2001.

[18] G. Ferretti, T. Bacchetti, S. Masciangelo, and V. Bicchiega, "HDL-paraoxonase and membrane lipid peroxidation: a comparison between healthy and obese subjects," Obesity, vol. 18, no. 6, pp. 1079-1084, 2010.
[19] S. A. Saeed, M. Elsharkawy, K. Elsaeed, and O. Fooda, "Paraoxonase-1 (PON1) activity as a risk factor for atherosclerosis in chronic renal failure patients," Hemodialysis International, vol. 12, no. 4, pp. 471-479, 2008.

[20] J. M. Ahn, H. J. Sung, Y. H. Yoon et al., "Integrated glycoproteomics demonstrates fucosylated serum paraoxonase 1 alterations in small cell lung cancer," Molecular \& Cellular Proteomics, vol. 13, no. 1, pp. 30-48, 2014.

[21] J. Camps, J. Marsillach, and J. Joven, "Measurement of serum paraoxonase-1 activity as a potential biomarker for chronic liver impairment," Clinica Chimica Acta, vol. 386, no. 1-2, pp. 114-115, 2007.

[22] K. Kotani, T. Yamada, and A. Gugliucci, "Paired measurements of paraoxonase 1 and serum amyloid $A$ as useful disease markers," BioMed Research International, vol. 2013, Article ID 481437, 4 pages, 2013.

[23] C. E. Furlong, S. M. Suzuki, R. C. Stevens et al., "Human PON1, a biomarker of risk of disease and exposure," Chemico-Biological Interactions, vol. 187, no. 1-3, pp. 355-361, 2010.

[24] R. J. Richter, G. P. Jarvik, and C. E. Furlong, "Paraoxonase 1 status as a risk factor for disease or exposure," Advances in Experimental Medicine and Biology, vol. 660, pp. 29-35, 2010.

[25] C. Zhou, J. Cao, L. Shang et al., "Reduced paraoxonase 1 activity as a marker for severe coronary artery disease," Disease Markers, vol. 35, no. 2, pp. 97-103, 2013.

[26] J. Marsillach, G. Aragonès, B. Mackness et al., "Decreased paraoxonase-1 activity is associated with alterations of highdensity lipoprotein particles in chronic liver impairment," Lipids in Health and Disease, vol. 9, article 46, 2010.

[27] M. Harel, A. Aharoni, L. Gaidukov et al., "Structure and evolution of the serum paraoxonase family of detoxifying and anti-atherosclerotic enzymes," Nature Structural and Molecular Biology, vol. 11, no. 5, pp. 412-419, 2004.

[28] O. Rozenberg, M. Shiner, M. Aviram, and T. Hayek, "Paraoxonase 1 (PON1) attenuates diabetes development in mice through its antioxidative properties," Free Radical Biology and Medicine, vol. 44, no. 11, pp. 1951-1959, 2008.

[29] A. Tward, Y.-R. Xia, X.-P. Wang et al., "Decreased atherosclerotic lesion formation in human serum paraoxonase transgenic mice," Circulation, vol. 106, no. 4, pp. 484-490, 2002.

[30] J. Yamashita, C. Iwamura, T. Ito et al., "Paraoxonase-1 suppresses experimental colitis via the inhibition of IFN- $\gamma$ production from CD4 T cells," The Journal of Immunology, vol. 191, no. 2, pp. 949-960, 2013.

[31] T. B. Cole, K. Jansen, S. Park, W.-F. Li, C. E. Furlong, and L. G. Costa, "The toxicity of mixtures of specific organophosphate compounds is modulated by paraoxonase 1 status," Advances in Experimental Medicine and Biology, vol. 660, pp. 47-60, 2010.

[32] L. G. Costa, B. E. McDonald, S. D. Murphy et al., "Serum paraoxonase and its influence on paraoxon and chlorpyrifosoxon toxicity in rats," Toxicology and Applied Pharmacology, vol. 103, no. 1, pp. 66-76, 1990.

[33] E. G. Duysen, K. Parikh, V. Aleti, V. Manne, O. Lockridge, and N. Chilukuri, "Adenovirus-mediated human paraoxonase1 gene transfer to provide protection against the toxicity of the organophosphorus pesticide toxicant diazoxon," Gene Therapy, vol. 18, no. 3, pp. 250-257, 2011.

[34] R. D. Gupta, M. Goldsmith, Y. Ashani et al., "Directed evolution of hydrolases for prevention of G-type nerve agent intoxication," Nature Chemical Biology, vol. 7, no. 2, pp. 120-125, 2011. 
[35] N.-N. Wang, H. Dai, L. Yuan et al., "Study of paraoxonase-1 function on tissue damage of dichlorvos," Toxicology Letters, vol. 196, no. 2, pp. 125-132, 2010.

[36] R. C. Stevens, S. M. Suzuki, T. B. Cole, S. S. Park, R. J. Richter, and C. E. Furlong, "Engineered recombinant human paraoxonase 1 (rHuPON1) purified from Escherichia coli protects against organophosphate poisoning," Proceedings of the National Academy of Sciences of the United States of America, vol. 105, no. 35, pp. 12780-12784, 2008.

[37] M. Valiyaveettil, Y. Alamneh, L. Biggemann et al., "In vitro efficacy of paraoxonase 1 from multiple sources against various organophosphates," Toxicology in Vitro, vol. 25, no. 4, pp. 905913, 2011.

[38] M. Valiyaveettil, Y. Alamneh, P. Rezk et al., "Protective efficacy of catalytic bioscavenger, paraoxonase 1 against sarin and soman exposure in guinea pigs," Biochemical Pharmacology, vol. 81, no. 6, pp. 800-809, 2011.

[39] M. Valiyaveettil, Y. Alamneh, P. Rezk et al., "Recombinant paraoxonase 1 protects against sarin and soman toxicity following microinstillation inhalation exposure in guinea pigs," Toxicology Letters, vol. 202, no. 3, pp. 203-208, 2011.

[40] L. Gaidukov, D. Bar, S. Yacobson et al., "In vivo administration of BL-3050: highly stable engineered PON1-HDL complexes," BMC Clinical Pharmacology, vol. 9, article 18, 26 pages, 2009.

[41] E. A. Ozer, A. Pezzulo, D. M. Shih et al., "Human and murine paraoxonase 1 are host modulators of Pseudomonas aeruginosa quorum-sensing," FEMS Microbiology Letters, vol. 253, no. 1, pp. 29-37, 2005.

[42] M. L. Estin, D. A. Stoltz, and J. Zabner, "Paraoxonase 1, quorum sensing, and P. aeruginosa infection: a novel model," Advances in Experimental Medicine and Biology, vol. 660, pp. 183-193, 2010.

[43] A. Aharoni, L. Gaidukov, S. Yagur, L. Toker, I. Silman, and D. S. Tawfik, "Directed evolution of mammalian paraoxonases PON1 and PON3 for bacterial expression and catalytic specialization," Proceedings of the National Academy of Sciences of the United States of America, vol. 101, no. 2, pp. 482-487, 2004.

[44] D. E. Lenz, D. Yeung, J. R. Smith, R. E. Sweeney, L. A. Lumley, and D. M. Cerasoli, "Stoichiometric and catalytic scavengers as protection against nerve agent toxicity: a mini review," Toxicology, vol. 233, no. 1-3, pp. 31-39, 2007.

[45] D. Rochu, E. Chabrière, and P. Masson, "Human paraoxonase: a promising approach for pre-treatment and therapy of organophosphorus poisoning," Toxicology, vol. 233, no. 1-3, pp. 47-59, 2007.

[46] F. Nachon, X. Brazzolotto, M. Trovaslet, and P. Masson, "Progress in the development of enzyme-based nerve agent bioscavengers," Chemico-Biological Interactions, vol. 206, pp. 536-544, 2013.

[47] Y. J. Rosenberg, J. Gearhart, L. Mao, X. Jiang, and S. HernandezAbanto, "Protection against paraoxon toxicity by an intravenous pretreatment with polyethylene-glycol-conjugated recombinant butyrylcholinesterase in macaques," Chemico-Biological Interactions, vol. 210, pp. 20-25, 2014.

[48] J. E. Chambers, "PON1 multitasks to protect health," Proceedings of the National Academy of Sciences of the United States of America, vol. 105, no. 35, pp. 12639-12640, 2008.

[49] F. M. Raushel, "Chemical biology: catalytic detoxification," Nature, vol. 469, no. 7330, pp. 310-311, 2011.

[50] M. Rosenblat and M. Aviram, "Paraoxonases role in the prevention of cardiovascular diseases," BioFactors, vol. 35, no. 1, pp. 98-104, 2009.
[51] H. Tavori, J. Vaya, and M. Aviram, "Paraoxonase 1 attenuates human plaque atherogenicity: relevance to the enzyme lactonase activity," Advances in Experimental Medicine and Biology, vol. 660, pp. 99-111, 2010.

[52] M. Valiyaveettil, Y. A. Alamneh, B. P. Doctor, and M. P. Nambiar, "Crossroads in the evaluation of paraoxonase 1 for protection against nerve agent and organophosphate toxicity," Toxicology Letters, vol. 210, no. 1, pp. 87-94, 2012.

[53] D. S. Kim, J. Marsillach, C. E. Furlong, and G. P. Jarvik, "Pharmacogenetics of paraoxonase activity: elucidating the role of high-density lipoprotein in disease," Pharmacogenomic, vol. 14, no. 12, pp. 1495-1515, 2013.

[54] A. E. Atay, M. A. Kaplan, O. Evliyaoglu, N. Ekin, and A. Isıkdogan, "The predictive role of paraoxonase 1 (PON1) activity on survival in patients with metastatic and nonmetastatic gastric cancer," La Clinica Terapeutica, vol. 165, no. 1, pp. 1-5, 2014.

[55] K. P. Radtke, "Method of using PON1 to decrease atheroma formation," United States Patent US 6,521,226 B1, 2002.

[56] T. C. Otto, C. K. Harsch, D. T. Yeung, T. J. Magliery, D. M. Cerasoli, and D. E. Lenz, "Dramatic differences in organophosphorus hydrolase activity between human and chimeric recombinant mammalian paraoxonase-1 enzymes," Biochemistry, vol. 48, no. 43, pp. 10416-10422, 2009.

[57] M. Sarkar, C. K. Harsch, G. T. Matic et al., "Solubilization and humanization of paraoxonase-1," Journal of Lipids, vol. 2012, Article ID 610937, 13 pages, 2012.

[58] M. Rai and H. Padh, "Expression systems for production of heterologous proteins," Current Science, vol. 80, no. 9, pp. 1121$1128,2001$.

[59] K. Terpe, "Overview of bacterial expression systems for heterologous protein production: from molecular and biochemical fundamentals to commercial systems," Applied Microbiology and Biotechnology, vol. 72, no. 2, pp. 211-222, 2006.

[60] S. Sahdev, S. K. Khattar, and K. S. Saini, "Production of active eukaryotic proteins through bacterial expression systems: a review of the existing biotechnology strategies," Molecular and Cellular Biochemistry, vol. 307, no. 1-2, pp. 249-264, 2008.

[61] R. J. Brushia, T. M. Forte, M. N. Oda, B. N. la Du, and J. K. Bielicki, "Baculovirus-mediated expression and purification of human serum paraoxonase 1," Journal of Lipid Research, vol. 42, no. 6, pp. 951-958, 2001.

[62] D. Josse, O. Lockridge, W. Xie, C. F. Bartels, L. M. Schopfer, and P. Masson, "The active site of human paraoxonase (PON1)," Journal of Applied Toxicology, vol. 21, supplement 1, pp. S7-S11, 2001.

[63] L. Tiegang, W. Nana, D. Heng, and Z. Min, "Polyethylene glycosylation prolongs the stability of recombinant human paraoxonase-1," Toxicology Letters, vol. 210, no. 3, pp. 366-371, 2012.

[64] M. Harel, B. Brumshtein, R. Meged et al., "3-D structure of serum paraoxonase 1 sheds light on its activity, stability, solubility and crystallizability," Arhiv za Higijenu Rada i Toksikologiju, vol. 58, no. 3, pp. 347-353, 2007.

[65] D. T. Yeung, D. E. Lenz, and D. M. Cerasoli, "Analysis of activesite amino-acid residues of human serum paraoxonase using competitive substrates," FEBS Journal, vol. 272, no. 9, pp. 22252230, 2005

[66] T. B. Cole, B. J. Walter, D. M. Shih et al., "Toxicity of chlorpyrifos and chlorpyrifos oxon in a transgenic mouse model of the human paraoxonase (PON1) Q192R polymorphism," Pharmacogenetics and Genomics, vol. 15, no. 8, pp. 589-598, 2005. 
[67] H. W. Eckerson, C. M. Wyte, and B. N. La Du, "The human serum paraoxonase/arylesterase polymorphism," The American Journal of Human Genetics, vol. 35, no. 6, pp. 1126-1138, 1983.

[68] C. E. Furlong, R. J. Richter, W. F. Li et al., "The functional consequences of polymorphisms in the human PON1 gene," in The Paraoxonases: Their Role in Disease Development and Xenobiotic Metabolism, vol. 6, pp. 267-281, Springer, Amsterdam, The Netherlands, 2008.

[69] C. Hassett, R. J. Richter, R. Humbert et al., "Characterization of cDNA clones encoding rabbit and human serum paraoxonase: the mature protein retains its signal sequence," Biochemistry, vol. 30, no. 42, pp. 10141-10149, 1991.

[70] G. Amitai, L. Gaidukov, R. Adani et al., "Enhanced stereoselective hydrolysis of toxic organophosphates by directly evolved variants of mammalian serum paraoxonase," The FEBS Journal, vol. 273, no. 9, pp. 1906-1919, 2006.

[71] P. Bajaj, R. K. Tripathy, G. Aggarwal, and A. H. Pande, "Characterization of human paraoxonase 1 variants suggest that his residues at 115 and 134 positions are not always needed for the lactonase/arylesterase activities of the enzyme," Protein Science, vol. 22, no. 12, pp. 1799-1807, 2013.

[72] P. Bajaj, G. Aggarwal, R. K. Tripathy, and A. H. Pande, "Interplay between amino acid residues at positions 192 and 115 in modulating hydrolytic activities of human paraoxonase 1," Biochimie, 2014.

[73] L. F. Vallejo and U. Rinas, "Strategies for the recovery of active proteins through refolding of bacterial inclusion body proteins," Microbial Cell Factories, vol. 3, no. 1, article 11, 2004.

[74] S. Graslund, P. Nordlund, J. Weigelt et al., "Protein production and purification," Nature Methods, vol. 5, no. 2, pp. 135-146, 2008.

[75] F. Baneyx and M. Mujacic, "Recombinant protein folding and misfolding in Escherichia coli," Nature Biotechnology, vol. 22, no. 11, pp. 1399-1408, 2004.

[76] E. García-Fruitós, E. Vázquez, C. Díez-Gil et al., "Bacterial inclusion bodies: making gold from waste," Trends in Biotechnology, vol. 30, no. 2, pp. 65-70, 2012.

[77] S. C. Makrides, "Strategies for achieving high-level expression of genes in Escherichia coli," Microbiological Reviews, vol. 60, no. 3, pp. 512-538, 1996.

[78] P. Bajaj, R. K. Tripathy, G. Aggarwal, A. K. Datusalia, S. S. Sharma, and A. H. Pande, "Refolded recombinant human paraoxonase 1 variant exhibit prophylactic activity against organophosphate poisoning," submitted for publication.

[79] V. Dechavanne, N. Barrillat, F. Borlat et al., "A high-throughput protein refolding screen in 96-well format combined with design of experiments to optimize the refolding conditions," Protein Expression and Purification, vol. 75, no. 2, pp. 192-203, 2011.

[80] D. I. Draganov, J. F. Teiber, A. Speelman, Y. Osawa, R. Sunahara, and B. N. La Du, "Human paraoxonases (PON1, PON2, and PON3) are lactonases with overlapping and distinct substrate specificities," Journal of Lipid Research, vol. 46, no. 6, pp. 12391247, 2005.

[81] J. Zhu, Y. Ze, C. Zhang et al., "High-level expression of recombinant human paraoxonase $1 \mathrm{Q}$ in silkworm larvae (Bombyx mori)," Applied Microbiology and Biotechnology, vol. 72, no. 1, pp. 103-108, 2006.

[82] T. C. Otto, S. A. Kasten, E. Kovaleva et al., "Purification and characterization of functional human paraoxonase-1 expressed in Trichoplusiani larvae," Chemico-Biological Interactions, vol. 187, no. 1-3, pp. 388-392, 2010.
[83] K. N. Gan, A. Smolen, H. W. Eckerson, and B. N. La Du, "Purification of human serum paraoxonase/arylesterase: evidence for one esterase catalyzing both activities," Drug Metabolism and Disposition, vol. 19, no. 1, pp. 100-106, 1991.

[84] L. Golmanesh, H. Mehrani, and M. Tabei, "Simple procedures for purification and stabilization of human serum paraoxonase1," Journal of Biochemical and Biophysical Methods, vol. 70, no. 6, pp. 1037-1042, 2008.

[85] O. Rochu, E. Chabrière, F. Renault, M. Elias, C. Cléry-Barraud, and P. Masson, "Stabilization of the active form(s) of human paraoxonase by human phosphate-binding protein," Biochemical Society Transactions, vol. 35, no. 6, pp. 1616-1620, 2007.

[86] P. Bajaj and A. H. Pande, "Stabilization studies on bacterially produced human paraoxonase 1 for improving its shelf life," Applied Biochemistry and Biotechnology, vol. 172, no. 8, pp. 3798-3809, 2014.

[87] M. J. Pikal, K. M. Dellerman, M. L. Roy, and R. M. Riggin, “The effects of formulation variables on the stability of freeze-dried human growth hormone," Pharmaceutical Research, vol. 8, no. 4, pp. 427-436, 1991.

[88] J. Bajgar, "Organophosphates/nerve agent poisoning: mechanism of action, diagnosis, prophylaxis, and treatment," Advances in Clinical Chemistry, vol. 38, pp. 151-216, 2004. 

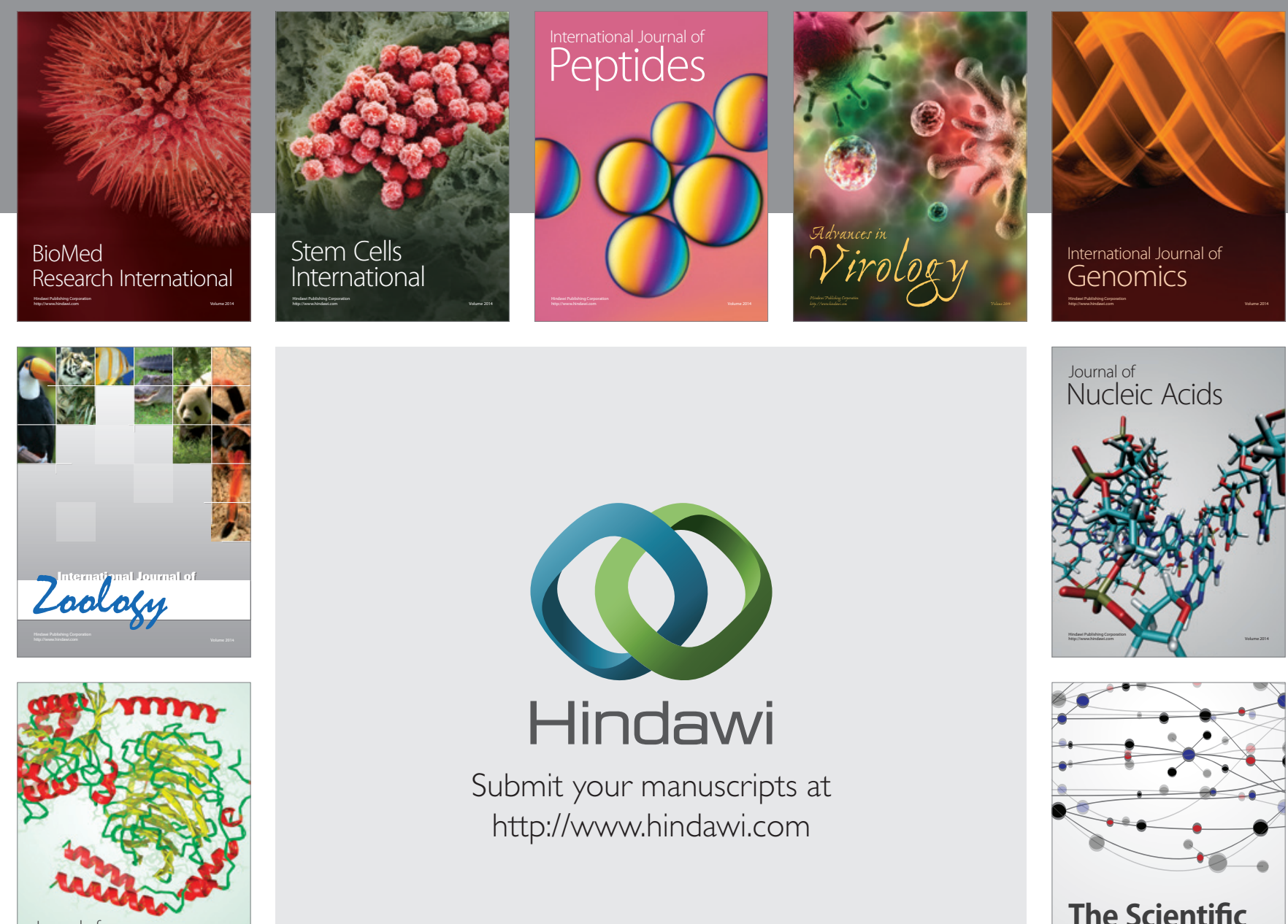

Submit your manuscripts at

http://www.hindawi.com

Journal of
Signal Transduction
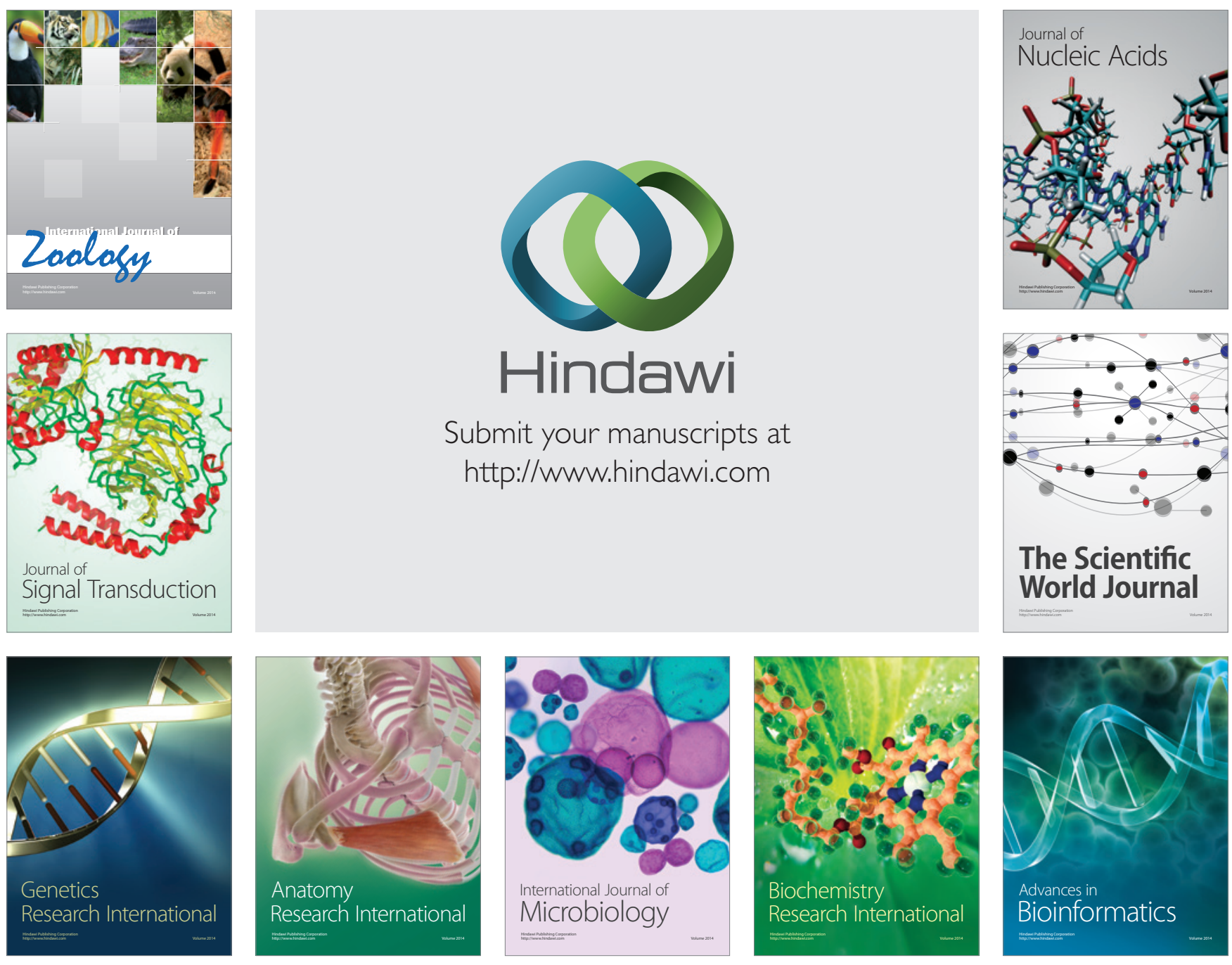

The Scientific World Journal
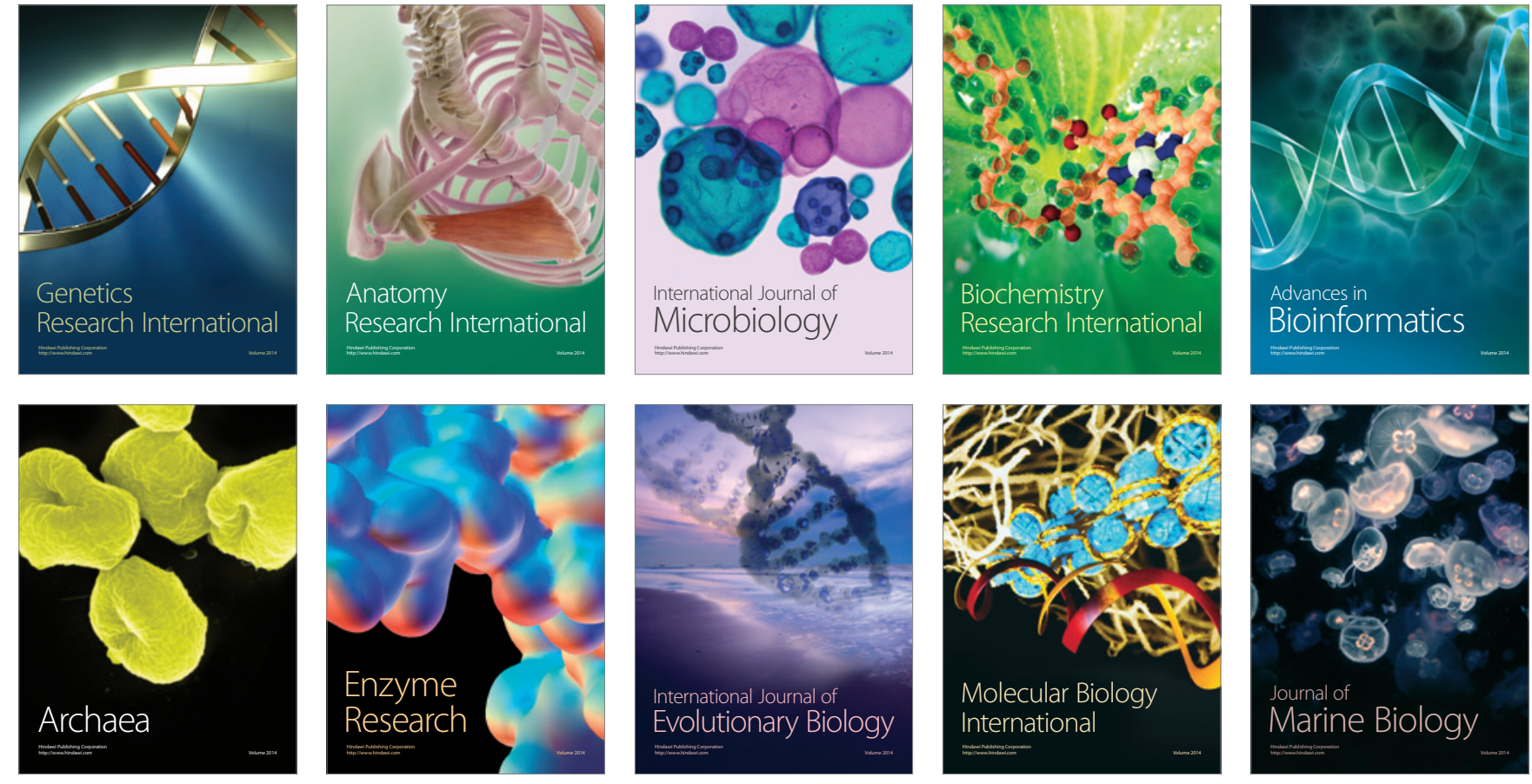